\title{
Pengukuran Tingkat Kemampuan Berpikir Siswa SMA Kabupaten Sumba Barat Daya Berdasarkan Taksonomi Bloom Revisi
}

\author{
*Melkianus Suluh, Yulita Adelfin Lede
}

Pendidikan Fisika STKIP Weetebula J1. Mananga Aba, Omba Calo, Kec. Loura,

Kabupaten Sumba Barat Daya-NTT, Indonesia

Corresponding email: Smelkieinstein@gmail.com

\section{Sejarah Artikel}

Dikirim: November 2021

Diterima: Desember 2021

Dipublikasi: Desember

2021

\section{Kata Kunci}

Fisika;

Keterampilan berpikir;

Model kredit parsial;

Taksonomi Bloom

\begin{abstract}
Abstrak
Penelitian ini bertujuan untuk mengukur tingkat kemampuan berpikir siswa SMA di Kabupaten Sumba Barat Daya pada mata pelajaran fisika. Jenis penelitian ini adalah penelitian deskriptif kuantitatif. Sampel penelitian terdiri dari 220 siswa dari 6 sekolah yang berbeda. Metode pengumpulan data yang digunakan dalam penelitian ini adalah metode tes melalui pemberian soal pilihan ganda beralasan. Teknik penilaian yang digunakan adalah teknik penilaian polytomous empat kategori dengan mengikuti model kredit parsial (PCM). Instrumen soal yang digunakan adalah instrumen kemampuan berpikir tingkat tinggi (HOTS). Hasil penelitian menunjukkan bahwa tingkat kemampuan berpikir berada pada kategori kurang dari empat kategori yang ditetapkan yaitu sangat baik, baik, cukup, dan kurang.
\end{abstract}

\section{Measurement of Thinking Ability Level of Southwest Sumba High School Students Based on Revised Bloom's Taxonomy}

\section{Article History}

Received: November 2021

Accepted: December 2021

Published: December 2021

Key Words

Physics:

Thinking Skills;

partial credit model;

Bloom's Taxonomy

How to cite this article?

\begin{abstract}
This study aims to measure the level of thinking ability of high school students in Southwest Sumba Regency on physics subjects. This type of research is descriptive quantitative research. The research sample consisted of 220 students from 6 different schools. The data collection method used in this study is a test method through the provision of reasoned multiple-choice questions. The assessment technique used is a four-category polytomous assessment technique by following the partial credit model (PCM). The question instrument used is the higher-order thinking ability (HOTS) instrument. The results showed that the level of thinking ability was in the category of less than the four defined categories, namely very good, good, sufficient, and poor.
\end{abstract}

Suluh, M., \& Lede, Y. (2021). Pengukuran Tingkat Kemampuan Berpikir Siswa SMA Kabupaten Sumba Barat Daya Berdasarkan Taksonomi Bloom Revisi. Lensa: Jurnal Kependidikan Fisika, 9(2), 170-177. doi:https://doi.org/10.33394/j-1kf.v9i2.4687

\section{PENDAHULUAN}

Fisika merupakan salah satu ilmu yang memiliki peranan yang sangat penting dalam perkembangan ilmu pengetahuan dan teknologi. Sebagai mata pelajaran, fisika telah diajarkan dari pendidikan dasar hingga pendidikan tinggi. Mata pelajaran ini diberikan untuk mengembangkan kemampuan berpikir kritis, pemecahan masalah, kolaborasi, komunikasi, kreatif dan inovasi. Kemampuan-kemampuan tersebut dalam perkembangannya dikenal sebagai keterampilan abad 21 yang dibutuhkan dalam membekali siswa agar mampu bertahan dalam menghadapi setiap tantangan dan perubahan zaman (Septikasari \& Frasandy, 2018).

Berpikir dalam kamus bahasa Indonesia diartikan sebagai kegiatan yang dilakukan seseorang dengan menggunakan akal untuk menimbang sebelum memutuskan sesuatu. Pengertian ini memberikan arti bahwa berpikir adalah proses penalaran yang dilakukan oleh seseorang dalam mempelajari dan menafsirkan suatu situasi atau peristiwa. Salah 
satu mata pelajaran yang memberikan kesempatan kepada siswa untuk mengasah kemampuan berpikirnya adalah fisika. Dalam konteks pembelajaran fisika, berpikir dapat diartikan sebagai proses ilmiah yang dilakukan oleh siswa, mulai dari menemukan masalah, mencari alternatif pemecahan, menemukan jawaban, menarik kesimpulan, dan menghasilkan ide yang lahir dari proses berpikir.

Fisika adalah "ilmu dasar yang mempunyai ciri-ciri yang meliputi suatu bentuk ilmu yang terdiri dari fakta, konsep, prinsip, hukum, postulat, dan teori serta metodologi ilmiah" (Mundilarto, 2010). Pernyataan ini menjadi logis mengingat fisika selalu berkaitan dengan fakta, yaitu kondisi yang terjadi di lingkungan alam yang kemudian membangun konsep diri peserta didik tentang alam. Berdasarkan konsep-konsep tersebut, muncul prinsip fisika, hukum fisika, postulat dan teori. Dengan demikian, belajar fisika dapat dilakukan secara dinamis dengan berlatih menerapkan konsep fisika melalui kegiatan eksperimen, mengumpulkan data, menganalisis data, menarik kesimpulan, dan mengkomunikasikan. Berdasarkan konsep tersebut, Fisika sebagai mata pelajaran memiliki tujuan membentuk siswa agar memiliki sikap positif terhadap keteraturan dan keindahan alam semesta, menumbuhkan sikap ilmiah, mampu merumuskan masalah, mengajukan dan menguji hipotesis, mengembangkan kemampuan nalar dalam berpikir analitis. , menguasai konsep dan prinsip fisika. , dan terampil dalam mengembangkan keterampilan. Tujuan pembelajaran fisika ini menggambarkan karakteristik manusia yang selalu berpikir dalam menghadapi masalah, mencari dan menemukan solusi serta membuat kesimpulan logis yang dapat diterima oleh akal sehat.

Seiring dengan perubahan dan perkembangan pendidikan, tuntutan kompetensi yang harus dikuasai peserta didik juga terus meningkat. Salah satu keterampilan yang harus dikuasai siswa adalah keterampilan berpikir tingkat tinggi, yaitu kemampuan berpikir yang tidak sekedar menghafal fakta atau tidak hanya sekedar mampu menyampaikan informasi tetapi merupakan bentuk keterampilan berpikir yang kompleks (Heong, dkk, 2011). Sedangkan menurut Anderson dan Krathwoll (2010), ada dua tingkatan kemampuan berpikir, yaitu kemampuan berpikir rendah (LOT) dan kemampuan berpikir tingkat tinggi (HOTS). Kemampuan berpikir rendah dalam Taksonomi Bloom revisi terdiri dari kemampuan mengetahui (C1), memahami (C2), dan menerapkan (C3). Sedangkan kemampuan berpikir tingkat tinggi meliputi kemampuan menganalisis (C4), mengevaluasi (C5), dan mencipta atau mencipta (C6). Untuk mengetahui kemampuan berpikir tinggi seseorang, menurut Lewy dan Aisyah N (2009 ada beberapa indikator yang dapat digunakan, indikator tersebut adalah: 1) menganalisis, yaitu menganalisis berbagai informasi yang diterima, memetakannya ke dalam bagianbagian dan berusaha mencari hubungan antar bagian yang ada. Selain itu, siswa dapat mengenali dan membedakan faktor-faktor dari suatu skenario, serta mampu merumuskan pertanyaan berdasarkan hasil kegiatan mengidentifikasi; 2) evaluasi, yaitu kemampuan untuk memberikan penilaian terhadap suatu kegiatan berdasarkan standar dan metode ilmiah untuk menghasilkan kesimpulan yang bermakna dan bermanfaat. Dalam prosesnya, siswa juga memiliki kemampuan untuk menerima atau menolak suatu ide atau pernyataan dan mampu membuat hipotesis berdasarkan kajian yang mendalam; 3) membuat atau membuat. Kemampuan pada tahap ini dapat dilihat dari kemampuan membuat generalisasi berdasarkan ide atau gagasan yang ada, kemampuan merancang suatu metode sebagai solusi pemecahan masalah, dan mampu menyusun elemen-elemen yang ada menjadi elemen-elemen baru. Menurut Putri, Istiyono dan Nurcahyanto (2016) untuk dapat mencapai kemampuan berpikir tingkat tinggi pada siswa diperlukan proses pembiasaan, sehingga terbentuk pola berpikir yang terarah dan terorganisir yang berdampak pada kemampuan menarik kesimpulan dan memecahkan suatu masalah. 
Namun kenyataan menunjukkan bahwa pola pembelajaran masih berorientasi pada pencapaian target kurikulum. Orientasi ini berdampak pada pola pembelajaran dan bentuk evaluasi yang dilakukan oleh guru. Hasil penelitian yang dilakukan oleh Ananda dan Fadhiraturrahmi (2017) menunjukkan bahwa pelaksanaan pembelajaran yang berorientasi pada pencapaian berpikir tingkat tinggi belum maksimal. Hal ini terlihat dari formulir evaluasi yang terkesan dibuat dadakan/kebetulan, soal diambil dari LKS yang diperjualbelikan, dan dari buku teks tanpa mempertimbangkan kelayakan tes sebagai alat evaluasi

Berdasarkan uraian tersebut, maka penelitian ini dilakukan dengan tujuan untuk mengetahui tingkat kemampuan berpikir siswa SMA dengan menggunakan taksonomi bloom yang telah direvisi sebagai basis pengukuran. Taksonomi pendidikan Bloom terdiri dari satu dimensi yang kemudian disempurnakan oleh Anderson dan Krathwoll. Dalam buku "Kerangka Landasan Untuk Pembelajaran, Pengajaran, dan Asesmen" (2010) taksonomi pendidikan dijabarkan menjadi dua dimensi, yaitu dimensi proses kognitif dan dimensi pengetahuan. Perbaikan dilakukan berdasarkan beberapa pertimbangan, yaitu (1) Guru sebagai pelaksana pendidikan dapat menggunakan buku tidak hanya sebagai dokumen sejarah tetapi juga sebagai sumber belajar yang harus digali maknanya; (2) perlunya menggabungkan pengetahuan dan pemikiran baru dalam suatu kerangka (Yulianti, 2016).

Dalam pembelajaran fisika, konsep taksonomi Bloom dapat dilihat dari kompleksitas mata pelajaran fisika sebagai bentuk pengetahuan yang terdiri dari cara berpikir, proses, dan sikap. Kompleksitas fisika juga ditunjukkan dari cara belajar fisika, bahwa untuk memahami fisika, siswa tidak hanya memahami hubungan antara fakta dan prinsip-prinsip sains/fisika tetapi harus dapat memahami proses dan landasan sains/fisika, karena konsep belajar fisika bukan sekedar belajar/mengajar. tentang fakta, prinsip, hukum, dan teori (Suluh, 2013). Menurut Sarjono (2016), dengan kompleksnya pelajaran fisika, siswa dapat "mengembangkan keterampilan berpikir kritis yang berguna dalam memecahkan masalah dalam kehidupan sehari-hari".

\section{METODE}

Jenis penelitian ini adalah penelitian kuantitatif dengan pendekatan deskriptif. Penelitian difokuskan pada pencapaian tingkat kemampuan berpikir siswa berdasarkan taksonomi Bloom dengan fokus pada kemampuan berpikir tingkat tinggi. Sampel penelitian ini adalah siswa kelas XI IPA SMA di Kabupaten Sumba Barat Daya yang berjumlah 220 orang dari 6 sekolah yang berbeda. Metode pengumpulan data yang digunakan dalam penelitian ini adalah metode tes melalui pemberian soal pilihan ganda beralasan. Teknik penilaian yang digunakan adalah teknik penilaian politomus empat kategori dengan mengikuti partial credit model (PCM) (Istiyono, et al, 2015).

Tabel 1. Kriteria Penilaian Soal Pilihan Ganda Beralasan

\begin{tabular}{ll}
\hline Skor & Kriteria \\
\hline 4 & Jika peserta didik menjawab soal benar dan alasan benar \\
3 & Jika peserta didik menjawab soal salah dan alasan benar \\
2 & Jika peserta didik menjawab soal benar dan alasan salah \\
1 & Jika peserta didik menjawab salah dan alasan salah \\
\hline
\end{tabular}

Pendekatan alternatif yang dapat digunakan untuk menganalisis tes adalah pendekatan teori respon item. Teori respon item merupakan model matematika yang artinya probabilitas subjek dalam menjawab item dengan benar bergantung pada kemampuan subjek dan karakteristik item yang kemudian dikembangkan menjadi model PCM (Rosidah et al, 2018). Soal fisika berbasis Bloomian pada materi fisika cocok untuk menggunakan model PCM karena memerlukan tahap identifikasi masalah hingga 
penyelesaian akhir. Oleh karena itu, penskoran model PCM layak digunakan dalam penilaian instrumen tes fisika berbasis Bloomian. Sedangkan untuk kategorisasi ketercapaian tingkat kemampuan berpikir siswa dilakukan dengan mengadaptasi kriteria dari Mardapi (2010).

Tabel 2. Kategorisasi Penilaian

\begin{tabular}{cl}
\hline Skor & Kategori \\
\hline$X \geq M i+1,5 S B x$ & Sangat Baik \\
$M i+1,5 S B x>X \geq M i$ & Baik \\
$M i \geq X \geq M i-1,5 S B x$ & Cukup \\
$X<M i-1,5 S B x$ & Kurang \\
\hline Dengan: \\
$\mathrm{X}=\quad$ skor aktual \\
$\mathrm{Mi}=\quad$ Mean ideal = 1/2 (skor tertinggi ideal + skor terendah ideal) \\
$\mathrm{SBX}=\quad$ Simpangan baku ideal = 1/6 (skor tetinggi ideal - skor terendah ideal)
\end{tabular}

Sedangkan analisis persentase digunakan persamaan (Sudijono, A, 2012).

$$
\text { Persentase }=\frac{\text { frekuensi yang dicari persentasenya }(f)}{\text { jumlah frekuensi atau banyaknya invidu }(N)} \times 100 \%
$$

\section{HASIL DAN PEMBAHASAN}

\section{Uji Validitas dan Reliabilitas Instrumen}

Instrumen tes sebelum digunakan diuji validitasnya dengan tujuan agar instrumen tersebut layak digunakan untuk mengukur tingkat kemampuan berpikir siswa. Berikut ini terlihat pada tabel 3 hasil analisis validitas instrumen tes menggunakan program quest.

Tabel 3. Hasil analisis ujicoba terbatas tes fisika higher order thinking skills (HOTS) berbasis Bloomian.

\begin{tabular}{llll}
\hline No & Keterangan & Estimasi item & Estimasi Testi \\
\hline 1 & Nilai rata-rata dan simpangan baku & $-0,02+0,31$ & $-1,03+0,27$ \\
2 & Reliabilitas & 0,75 & 0,71 \\
3 & Nilai rata-rata dan simpangan INFIT MNSQ & $1,00+0,04$ & $1,00+0231$ \\
4 & Nilai rata-rata dan simpangan OUTFIT MNSQ & $1,00+0,08$ & $1,00+0,24$ \\
5 & Nilai rata-rata dan simpangan baku INFIT t & $0,02+0,43$ & $0,07+0,70$ \\
6 & Nilai rata-rata dan simpangan baku OUTFIT t & $0,01+0,59$ & $0,09+0,57$ \\
7 & Item atau testi skor 0 & 0 & 0 \\
8 & Item atau testi skor perfect & 0 & 0 \\
\hline
\end{tabular}

Berdasarkan kriteria dari model Rasch, suatu item atau tes dinyatakan fit jika INFIT MNSQ berada pada kisaran -1,77 hingga 1,30. Dan suatu item dinyatakan tidak fit dengan model Rasch jika nilai t INFIT <-2.0 atau +2.0 . Hasil analisis menunjukkan bahwa nilai goodness of fit semua item berada pada rentang 0.83 sampai dengan 1.20. Dengan demikian, semua item yang dianalisis fit menurut PCM.

Hasil analisis juga menunjukkan reliabilitas tes cukup baik, berkisar antara 0,7 sampai 0,8 (Sumintono \& Widhiarso, 2014). Dengan demikian, butir soal dapat digunakan untuk mengukur tingkat kemampuan berpikir siswa. Persentase jawaban siswa untuk setiap aspek dan sub aspek dapat dilihat pada tabel berikut.

Tabel 4. Persentase jawaban peserta tes setiap aspek dan sub aspek HOTS

\begin{tabular}{llllll}
\hline \multirow{2}{*}{ Aspek } & \multirow{2}{*}{ Sub Aspek } & \multicolumn{3}{l}{ Kategori } \\
\cline { 3 - 5 } & & $1(\%)$ & $2(\%)$ & $3(\%)$ & $4(\%)$ \\
\hline Menganalsis & Membedakan & 51,6 & 11,4 & 17,9 & 19,1 \\
\hline
\end{tabular}




\begin{tabular}{llllll}
\hline \multirow{2}{*}{ Aspek } & \multirow{2}{*}{ Sub Aspek } & \multicolumn{3}{l}{ Kategori } & \\
\cline { 3 - 6 } & & $1(\%)$ & $2(\%)$ & $3(\%)$ & $4(\%)$ \\
\cline { 2 - 5 } & Mengorganisasikan & 46,6 & 26,3 & 9,2 & 17,9 \\
\multirow{3}{*}{ Mengevaluasi } & Mengatributkan & 49,0 & 15,4 & 19,8 & 15,8 \\
& Memeriksa & 40,8 & 26,8 & 18,1 & 14,3 \\
Mencipta & Mengkritik & 33,1 & 28,3 & 20,8 & 17,8 \\
& Merumuskan & 34,9 & 16,7 & 11 & 37,4 \\
& Merencanakan & 36,6 & 17,5 & 37 & 8,9 \\
& Memproduksikan & 33,3 & 7,3 & 21,2 & 38,2 \\
\hline
\end{tabular}

Sub aspek yang memiliki persentase tertinggi pada kategori 1 adalah sub aspek pembeda sebesar 51,6\% dan dapat dikatakan bahwa sub aspek tersebut merupakan sub aspek yang paling sulit. Sedangkan sub aspek tertinggi pada kategori 4 adalah sub aspek penghasil sebesar $38,2 \%$, artinya sub aspek tersebut dinyatakan paling mudah. Lebih jelasnya, persentase jawaban siswa untuk setiap aspek dan sub-aspek ditunjukkan pada Gambar 1 berikut.

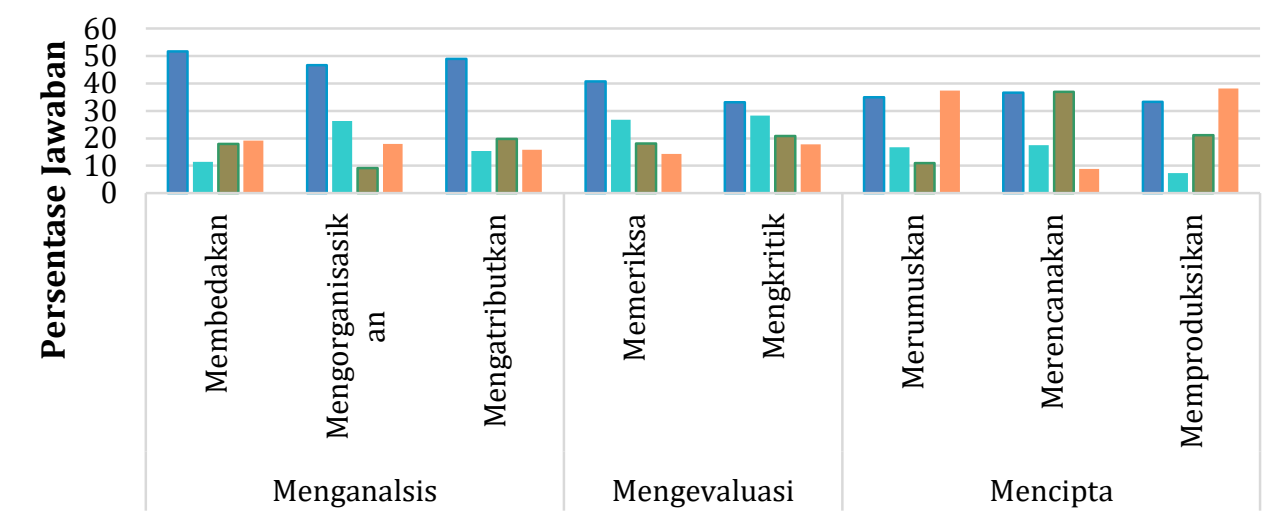

Aspek dan Sub Aspek HOTS berbasis Bloomian

Kategori $1(\%) \quad \square$ Kategori $2(\%) \quad \square$ Kategori $3(\%) \quad \square$ Kategori 4 (\%)

Gambar 1. Persentase Jawaban untuk setiap kategori

\section{Pengukuran Tingkat Kemampuan Berpikir}

Tingkat kemampuan berpikir yang diukur dalam penelitian ini adalah kemampuan berpikir tingkat tinggi yang terdiri dari kemampuan menganalisis, mengevaluasi, dan mencipta. Kemampuan berpikir dalam penelitian ini diklasifikasikan menjadi 4 tingkatan, yaitu: sangat tinggi, tinggi, sedang, dan rendah. Hasil pengukuran ini diharapkan dapat menjadi bahan pertimbangan guru fisika dalam melaksanakan proses pembelajaran. Dalam penelitian ini, data tingkat kemampuan berpikir tingkat tinggi siswa berdasarkan jawaban 20 butir soal polytomous (soal pilihan ganda beralasan). Nilai perolehan siswa dianalisis secara deskriptif statistik.

Pengukuran tingkat kemampuan berpikir siswa dilakukan dengan cara menganalisis hasil jawaban siswa terhadap soal tes yang diberikan. Berikut hasil analisis deskriptif jawaban tes berdasarkan kriteria yang dikemukakan Mardapi (2010).

Tabel 5. Data Tingkat Kemampuan berpikir Peserta Didik

\begin{tabular}{clllll}
\hline No & \multicolumn{2}{l}{ Tingkat Kemampuan berpikir } & Nomor Soal & Kategori & \\
\hline \multirow{2}{*}{ Menganalisis } & Membedakan & $1-2$ & Cukup & \\
& & Mengurutkan & $3-4$ & Kurang & Kurang \\
& Mengatribusi & $5-8$ & Kurang & \\
& Mengevaluasi & Memeriksa & $9-12$ & Kurang & Kurang
\end{tabular}




\begin{tabular}{lllll}
\hline No & Tingkat Kemampuan berpikir & Nomor Soal & Kategori & \\
\hline \multirow{2}{*}{ Mencipta } & Mengkritik & $13-15$ & Kurang & \\
& Merumuskan & $16-17$ & Kurang & \\
& Merencanakan & $18-19$ & Kurang & Kurang \\
& Memproduksi & 20 & Kurang & \\
\hline
\end{tabular}

Tabel 6. Kategori Pencapaian Tingkat Kemampuan Berpikir

\begin{tabular}{ll}
\hline Kategori & Persen \\
\hline Sangat Tinggi & - \\
Tinggi & - \\
Cukup & 26,83 \\
Rendah & 73,17 \\
\hline
\end{tabular}

Hasil analisis menunjukkan bahwa tingkat kemampuan berpikir tinggi siswa secara umum masih jauh dari harapan. Terlihat bahwa prestasi belajar siswa yang terbaik berada pada kategori cukup sebesar $26,83 \%$ sedangkan $73,17 \%$ berada pada kategori rendah. Data tersebut menunjukkan bahwa tingkat kemampuan berpikir siswa yang dijadikan sampel dalam penelitian ini masih jauh dari harapan. Dari ketiga tingkat kemampuan berpikir tingkat tinggi tersebut, skor prestasi tertinggi yang diperoleh adalah pada tingkat menganalisis sub indikator membedakan dengan capaian pada kategori cukup.

Berdasarkan data tersebut, peneliti mencoba mengkonfirmasi kepada beberapa guru fisika mengenai hasil yang dicapai siswa. Beberapa guru menyatakan bahwa rendahnya prestasi siswa pada ulangan yang diberikan disebabkan oleh ketidakbiasaan siswa dalam mengerjakan soal-soal HOTS. Selama ini soal-soal yang telah disusun belum menekankan soal-soal HOTS sebagai soal-soal yang diujikan. Soal HOTS yang dikembangkan guru lebih diarahkan pada penyesuaian kata kunci yang terdapat pada Kompetensi Dasar. Selain itu, guru belum pernah menyusun soal dalam bentuk polytomus yaitu soal pilihan ganda. Selama ini guru lebih berkonsentrasi pada penyusunan soal pilihan ganda biasa dengan materi yang sesuai dengan yang dikuasai siswa.

Sementara itu, guru lain menambahkan bahwa rendahnya hasil tes juga disebabkan pada masa pandemic covid-19 proses pembelajaran di sekolah tidak berlangsung secara maksimal. Sementara itu, guru lain menambahkan, rendahnya hasil tes juga disebabkan selama pandemi COVID-19, proses pembelajaran di sekolah tidak berlangsung secara maksimal. Proses pembelajaran yang tidak maksimal berdampak pada tingkat kedalaman dan keluasan materi yang diajarkan kepada siswa. Namun diakui guru bahwa pelaksanaan pembelajaran berbasis HOTS masih menjadi tantangan. Tantangan ini disebabkan siswa belum terbiasa berpikir kritis, keterbatasan kemampuan siswa, dan keterbatasan sarana dan prasarana belajar yang dimiliki siswa. Berdasarkan hasil tersebut menggambarkan bahwa rendahnya tingkat kemampuan berpikir tingkat tinggi siswa pada umumnya disebabkan oleh kurangnya pembiasaan dan pelatihan yang dilakukan oleh guru (Musrikah, 2018; Ariansyah, 2019). Belum terbiasanya siswa dalam mengerjakan soal HOTS atau proses pembelajaran berbasis HOTS berpengaruh terhadap pola berpikir siswa. Menurut Musrikah (2018)16 keberhasilan negara lain dalam mencapai tingkat kemampuan berpikir tingkat tinggi yang baik tidak lepas dari proses pembiasaan dalam kegiatan pembelajaran di kelas. Dari beberapa pernyataan tersebut dapat dikemukakan bahwa pola pembiasaan dan proses pembelajaran sangat berpengaruh dan berdampak pada tingkat prestasi berpikir siswa. Siswa dapat mencapai tingkat kemampuan berpikir yang baik apabila telah dibiasakan dengan kegiatan belajar. 


\section{KESIMPULAN}

Berdasarkan hasil analisis data, maka kesimpulan yang diperoleh dalam penelitian ini adalah: kemampuan berpikir tingkat tinggi siswa masih jauh dari harapan, yaitu tergolong dalam kategori kurang. Siswa masih mengalami kesulitan dalam mengerjakan soal-soal keterampilan berpikir tingkat tinggi. Rendahnya kemampuan tersebut disebabkan oleh beberapa faktor, antara lain rendahnya tingkat kemampuan siswa, proses pembelajaran yang tidak maksimal pada masa pandemi, dan siswa belum terbiasa mengerjakan soalsoal berpikir tingkat tinggi berbentuk politomus.

\section{SARAN}

Berdasarkan hasil penelitian, beberapa rekomendasi yang dapat diberikan adalah: 1) Bagi guru fisika diharapkan dapat mengembangkan pembelajaran yang dapat mengembangkan kemampuan berpikir tingkat tinggi siswa, dan membiasakan siswa mengerjakan soal berbasis HOTS; 2) Bagi peneliti diharapkan dapat melakukan penelitian lebih lanjut dengan topik kajian tentang kemampuan berpikir analitis, berpikir kreatif, dan berpikir kritis untuk mengetahui bentuk-bentuk kemampuan yang dimiliki dan dicapai siswa

\section{DAFTAR PUSTAKA}

Anderson, \& Krathwohl. (2010). Kerangka Landasan Untuk Pembelajaran, Pengajaran, dan Asesmen. Yogyakarta: Pustaka Pelajar.

Istiyono, E., Mardapi, D., \& Suparno. (2015). Effectiveness of reasoned objective choice test to measure higher order thinking skills in physics implementing of curiculum 2013. International Conference on Education Research and Evaluation.

Lewy, Zulkardi, \& Aisyah. (2099). Pengembangan Soal Untuk Mengukur Kemampuan Berpikir Tingkat Tinggi Pokok Bahasan Barisan dan Deret Bilangan di Kelas IX Akselerasi SMP Xaverius Maria Palembang. Jurnal Pendidikan Matematika Universitas Sriwijaya.

Mardapi, D. (2008). Teknik Penyusunan Instrumen Tes dan Nontes. Yogyakarta: Mitra Cendekia Offset.

Mundilarto. (2010). Penilaian Hasil belajar Fisika. Yoyakarta:: Pusat Pengembangan Instruksional Sains (P2IS) FMIPA-Universitas Negeri Yogyakarta.

Musrikah, M. (2018). Higher Order Thingking Skill (Hots) Untuk Anak Sekolah Dasar Dalam Pembelajaran Matematika. Martabat:. Jurnal Perempuan Dan Anak., 339360.

PUSKURBUK. (2013). Kurikulum 2013 Pedoman Guru Mata Pelajaran FISIKA Untuk Sekolah Menengah Atas (SMA)/ Madrasah Aliyah (MA). Jakarta.: Pusat Kurikulum Dan Perbukuan Badan Penelitian Dan Pengembangan Kementerian Pendidikan Dan Kebudayaan.

Putri, Istiyono, \& Nurcahyanto. (2016). Pengembangan Instrumen Tes Keterampilan Berpikir Kritis Dalam Bentuk Pilihan Ganda Beralasan (Politomus) Di DIY. Unnes Physics Education Journal, 76-84.

Rizki, A., \& Fadhilaturrahmi. (2017). Evaluasi Pembelajaran IPS Berbasis Taksonomi Bloom Dua Dimensi di Sekolah Dasar. Jurnal Basicedu, 12-21.

Rosidah, N. A., Ramalis, T. R., \& Suyana, I. (2018). Karakteristik Tes Keterampilan Berpikir Kritis (KBK) Berdasarkan Pendekatan Teori Respon Butir. Jurnal Inovasi Dan Pembelajaran Fisika, 54-63.

Sarjono. (2016). Pengembangan Soal Fisika Sma/Ma Politomus Berbasis Taksonomi Bloom Revisi. Jurnal Madaniyah, 1-16.

Septikasari, \& Frasandy. (2018). Keterampilan 4c Abad 21 Dalam Pembelajaran Pendidikan Dasar. Jurnal Tarbiyah Al-Awlad, 112-122. 
Sudijono, A. (2012). Pengantar Statistik Pendidikan. Jakarta: PT. Raja Grafindo Persada. Suluh, M. (2013). Suluh, Melkianus (2013). Studi Keterlaksanaan Pembelajaran Fisika Berbasis Scientific Approach di SMA Kota Yogyakarta. Thesis. Yogyakarta: Universitas Negeri Yogyakarta.

Sumintono, B., \& Widhiarso. (2014). Sumintono dan Widhiarso. (2014). Aplikasi Model Rasch Untuk Penelitian Ilmu-Ilmu Sosial. Cimahi.: Trim Komunikata Publishing House.

Yulianti. (2017). Pengembangan Alat Evaluasi Hasil Belajar Mata Pelajaran Pendidikan Agama Islam Berbasis Taksonomi Bloom Dua Dimensi. Journal of Islamic Education Studies, 407-430. 